\title{
Perception of Employees towards TPM implementation in Foundry Industry with Reference to Coimbatore District
}

\author{
Elamaran N. ${ }^{1}$, V. R. Nedunchezhian ${ }^{2}$, \& P. K. Suresh Kumar ${ }^{3}$ \\ ${ }^{1}$ Research Scholar, College of Management \& Commerce, Srinivas University, Mangalore - 575 \\ 001, India. E-mail: maranela2001@yahoo.com \\ ${ }^{2}$ Professor and Head, Center Head Finance, KCT Business School, Coimbatore-641049, India. \\ ${ }^{3}$ Research Professor, College of Management and Commerce, Mangalore - 575 001, India.
}

Area/Section: Business Management.

Type of the Paper: Empirical Study.

Type of Review: Peer Reviewed as per $|\mathrm{C}| \mathrm{O}|\mathrm{P}| \mathrm{E} \mid$ guidance.

Indexed in: OpenAIRE.

DOI: http://doi.org/10.5281/zenodo.4044675

Google Scholar Citation: IJMTS.

\section{How to Cite this Paper:}

Elamaran, N., Nedunchezhian, V. R. \& Suresh Kumar, P. K. (2020). Perception of Employees towards TPM implementation in Foundry Industry with Reference to Coimbatore District. International Journal of Management, Technology, and Social Sciences (IJMTS), 5(2), 167-

186. DOI: http://doi.org/10.5281/zenodo.4044675

International Journal of Management, Technology, and Social Sciences (IJMTS)

A Refereed International Journal of Srinivas University, India.

(C) With Authors.

\section{(c) (7) (8)}

This work is licensed under a Creative Commons Attribution-Non-Commercial 4.0 International License subject to proper citation to the publication source of the work.

Disclaimer: The scholarly papers as reviewed and published by the Srinivas Publications (S.P.), India are the views and opinions of their respective authors and are not the views or opinions of the SP. The SP disclaims of any harm or loss caused due to the published content to any party. 


\title{
Perception of Employees towards TPM implementation in Foundry Industry with Reference to Coimbatore District
}

\author{
Elamaran N. ${ }^{1}$, V. R. Nedunchezhian ${ }^{2}$, \& P. K. Suresh Kumar ${ }^{3}$ \\ ${ }^{1}$ Research Scholar, College of Management \& Commerce, Srinivas University, Mangalore - 575 \\ 001, India. E-mail: maranela2001@ yahoo.com \\ ${ }^{2}$ Professor and Head, Center Head Finance, KCT Business School, Coimbatore-641049, India. \\ ${ }^{3}$ Research Professor, College of Management and Commerce, Mangalore - 575 001, India.
}

\begin{abstract}
Total Productive Maintenance (TPM) is really an economical method by means it will be able to keep up with the shrub, machinery/ gear in addition to resources inside rewarding condition throughout minimum expense. Well retained machineries leads to productivity. With the companies who are into the foundry industry, the TPM quality policy is to consistently provide superior quality products and services, surpassing customer expectations on time at affordable prices. The main objective is that to study the roles of various people involved in the TPM and to identify the tangible and intangible benefits of TPM. For this a sample of 130 was collected from the respondents were analysed by descriptive statistics, regression analysis, Kruskallwallis, Rank correlation, and SEM analysis. The conclusion is that the TPM is effectively implemented with the organisation and further slight changes have to be made which leads to cost effectiveness towards the company.

Keywords: Industry 4.0, Indian Engineering Industry, Institutional Theory, Resource-Based Theory, Industry 4.0 Implementation.
\end{abstract}

\section{INTRODUCTION :}

Total Productive Maintenance (TPM) can be described as a procedure or even method. This technique was initially launched simply by Western within 1952. That is the expansion in order to TQM. TPM is really a clear plus structured system which in turn gets rid of the lessening due to breaking down associated with devices plus materials by simply determining in addition to fighting most factors behind accessories crack lows and even program down-time [1]. TPM is really a reasonably priced method via this method it will be able to keep up with the machinery/ products together with equipment's in a minimum price. Okay managed devices result in efficiency. There's a connection among price associated with repair plus price regarding high quality. All of us cannot believe high quality results while not high-quality advice and something from the essential insight is usually TPM. Price sustained to keep gear is usually give some thought to like an excellent price. There is a possibility of achieving quality through continuous effort by putting all the persons who are directly involving in maintenance of production while implementing TPM [2-3]. Europeans in addition to People in America thought that all manufacturing is definitely reduced standing function and even servicing offers understanding compared to development mainly because upkeep will not participate straight inside income era instead it really is handled seeing that program over head. Although Western provides established that will manufacturing repairs and maintenance offers a higher position [4]. Efficiency includes price, high quality, total, attempts, period, remodel, tidbit, functioning atmosphere together with a competition involving the business. Each construction business really wants to obtain efficiency plus TPM performs the main position inside it. This study is concerned with the assessment of TPM as a tool to improve the organization's performance [5-7].

\section{STATEMENT OF THE PROBLEM :}

The problem is that TPM is really a program for that group to keep up given good quality also to produce an 
atmosphere by which every worker, each and every job every procedure includes a range pertaining to enhancement so when the business creates persists enhancement tradition this impact upon high quality, output plus competition of this business which is doable to attain via whole effective routine maintenance and based on the same the following are considered to be the problem towards the study,

- What do employees perceive about implementation of TPM?

- Whether age has any relation towards and behavior of employees change after TPM implementation?

- Is there any relation between experience of the employees, organization implementing TPM and problems encountered while implementing TPM?

- What are the reasons for organisations in foundry industry to have TPM with their concerns?

- What is the impact of problems faced by employees in implementation of TPM towards behavior of employees change after TPM implementation?

\section{OBJECTIVES OF THE STUDY :}

The major objectives of the study are :

- To evaluate the perception of employees towards TPM with their company.

- To compare the relation between age and behavior of employees change after TPM implementation.

- To compare the relation between organization implementing TPM and problems encountered while implementing TPM

- To compare the industrial experience and problems encountered while implementing TPM.

- To analyse the reason for organisation having TPM.

- To find out the impact of problems faced by employees in implementation of TPM towards behavior of employees change after TPM implementation

\section{SCOPE OF THE STUDY :}

This research study mainly focuses on Total Productive Maintenance and its impact on organization performance. In this study foundry industry in Coimbatore was selected in which TPM is implemented. The main scope of the study is that it will help the top management of the industry to know about the perception of employees towards maintaining productivity which may help them in the future decision making process.

\section{REVIEW OF LITERATURE :}

Masud, A.K.M. et al. [24] discovered that notion of TPM could be put on some sort of Bangladeshi dress manufacturing facility effectively. Throughout the contemporary extremely aggressive industry, TPM is usually typically the equipment of which stand up in between good results in addition to overall disappointment for a lot of businesses. Halim Mad Lazim [25] talked about a part of initial research obtaining concentrating on 2 primary TPM methods specifically independent servicing plus prepared upkeep inside a Malaysian SME. The outcomes recommended essential facets of independent servicing in addition to organized upkeep actions that will be added towards the enhancement within high quality and even price. Halim Mad Lazim, T. et al. [26] talked about the elements of initial research selecting concentrating on 2 major TPM methods including independent servicing plus designed upkeep inside a Malaysian SME. The end result recommended essential facets of independent servicing in addition to prepared upkeep things to do that will led towards the enhancement within top quality and even price.

One Yoon Seng, et al. [9] tried to evaluate the TPM execution in the viewpoint of the growing nation like Malaysia. It had been figured the particular magnitude associated with both human being plus procedure focused techniques would most likely result in increased TPM guidelines within the large business. Nevertheless, the particular effect associated with Human oriented Approach is deemed higher afterward Process-oriented Technique within cultivating an increased amount regarding TPM inclusion when the modifications and even playing god within the large business are even more associated with individual problems. Therefore, typically the administration needs to poise the two tactics to get the particular maximum a result of execution. There are many scholarly research papers published on the concept, review, and 
International Journal of Management, Technology, and Social

implementation of TPM along with case studies in different industry sectors and some of the important results on related work are listed in Table 1 with the research area, research focus, and reference.

Table 1 : Related research work on Total Productive Maintenance (TPM) in different Organizations

\begin{tabular}{|c|c|c|c|}
\hline $\begin{array}{l}\text { S. } \\
\text { No. }\end{array}$ & Research Area & Research focus & Reference \\
\hline 1 & TPM Concept & Introduction to TPM & $\begin{array}{l}\text { Venkatesh, J. (2007). } \\
\text { [1] }\end{array}$ \\
\hline 2 & TPM Concept & $\begin{array}{l}\text { TPM in support processes: an enabler } \\
\text { for operation excellence }\end{array}$ & $\begin{array}{l}\text { Andersson, R. et al. } \\
(2015) .[2]\end{array}$ \\
\hline 3 & TPM Concept & $\begin{array}{l}\text { Relationship between } \\
\text { performanc }\end{array}$ TPM and & $\begin{array}{l}\text { Brah, S. A. et al. (2004). } \\
\text { [3] }\end{array}$ \\
\hline 4 & TPM Concept & $\begin{array}{l}\text { World class manufacturing framework } \\
\text { by using six- igma TPM and Lean }\end{array}$ & $\begin{array}{l}\text { Okhovat, M. A. et al. } \\
\text { (2012). [4] }\end{array}$ \\
\hline 5 & Literature Review on TPM & Total productive maintenance & $\begin{array}{l}\text { Ahuja, I. P. S. et al. } \\
(2008) .[5]\end{array}$ \\
\hline 6 & Literature Review on TPM & $\begin{array}{l}\text { Analysis of Barriers and Enablers for } \\
\text { Effective Implementation TPM }\end{array}$ & $\begin{array}{l}\text { Gupta, A. et al. (2019). } \\
\text { [6] }\end{array}$ \\
\hline 7 & Literature Review on TPM & Failure mode effect analysis \& TPM & $\begin{array}{l}\text { Waghmare, S. N. et al } \\
\text { (2014). [7] }\end{array}$ \\
\hline 8 & Literature Review on TPM & $\begin{array}{l}\text { Integration of TPM elements with ISO } \\
9001 \text { standard }\end{array}$ & $\begin{array}{l}\text { Sivaram, N. M. et al. } \\
\text { (2012). [8] }\end{array}$ \\
\hline 9 & Literature Review on TPM & Investigation of human aspect in TPM & $\begin{array}{l}\text { One Yoon Seng et al. } \\
(2010) .[9]\end{array}$ \\
\hline 10 & Literature Review on TPM & Investigation of human aspect in TPM & $\begin{array}{l}\text { Kulkarni, A. et al. } \\
\text { (2013). [10] }\end{array}$ \\
\hline 11 & TPM implementation & TPM implementation practice & $\begin{array}{l}\text { Jain, A. et al. (2014). } \\
\text { [11] }\end{array}$ \\
\hline 12 & TPM implementation & $\begin{array}{llll}\text { TPM implementation } & \text { in } & \text { a } \\
\text { manufacturing organisation } & & \\
\end{array}$ & $\begin{array}{l}\text { Ahuja, I. P. S. et al. } \\
\text { (2008). [12] }\end{array}$ \\
\hline 13 & TPM implementation & $\begin{array}{l}\text { To enhance the overall equipment } \\
\text { effectiveness in medium scale industrie }\end{array}$ & $\begin{array}{l}\text { Nallusamy, S. et al. } \\
(2018) .[13]\end{array}$ \\
\hline 14 & TPM implementation & $\begin{array}{l}\text { In the manufacturing companies: a } \\
\text { system dynamics approach }\end{array}$ & $\begin{array}{l}\text { Shahanaghi, K. et al. } \\
\text { (2009). [14] }\end{array}$ \\
\hline 15 & TPM implementation & TPM Implementation methodology & $\begin{array}{l}\text { Kedaria, V. D. et al. } \\
(2014) .[15]\end{array}$ \\
\hline 16 & TPM implementation & $\begin{array}{l}\text { implementation in manufacturing } \\
\text { environment }\end{array}$ & $\begin{array}{l}\text { Kocher, G. et al. (2012). } \\
{[16]}\end{array}$ \\
\hline 17 & TPM implementation & In pharmaceutical manufacturing & $\begin{array}{l}\text { Friedli, T. et al. (2010). } \\
\text { [17] }\end{array}$ \\
\hline 18 & TPM implementation & $\begin{array}{l}\text { An ISM approach for modelling the } \\
\text { enablers }\end{array}$ & $\begin{array}{l}\text { Attri, R. et al. (2013). } \\
\text { [18] }\end{array}$ \\
\hline 19 & TPM implementation & $\begin{array}{l}\text { A graph theoretic approach to evaluate } \\
\text { the intensity of barrier }\end{array}$ & $\begin{array}{l}\text { Attri, R. et al. (2014). } \\
\text { [19] }\end{array}$ \\
\hline 20 & TPM implementation & $\begin{array}{lll}\text { In Medium } & \text { Scale } & \text { Manufacturing } \\
\text { Industry } & & \\
\end{array}$ & $\begin{array}{l}\text { Punna Rao et al. (2020). } \\
{[20]}\end{array}$ \\
\hline 21 & TPM implementation & $\begin{array}{l}\text { TPM \& overall equipment effectiveness } \\
\text { evaluation }\end{array}$ & $\begin{array}{l}\text { Kathleen E. et al. } \\
\text { (1999). [21] }\end{array}$ \\
\hline
\end{tabular}


International Journal of Management, Technology, and Social

\begin{tabular}{|c|c|c|c|}
\hline 22 & Case Studies on TPM & Chemical manufacturing company & $\begin{array}{l}\text { Mwanza, B. G. et al. } \\
\text { (2015). [22] }\end{array}$ \\
\hline 23 & Case Studies on TPM & Implementation of TPM & $\begin{array}{l}\text { Chan, F. T. S. et al. } \\
\text { (2005). [23] }\end{array}$ \\
\hline 24 & Case Studies on TPM & Burlingtons limited, Bangladesh & $\begin{array}{l}\text { Masud, A. K. M. et al. } \\
\text { (2007). [24] }\end{array}$ \\
\hline 25 & Case Studies on TPM & Malaysian SME experience & $\begin{array}{l}\text { Halim Mad Lazim } \\
\text { (2016). [25] }\end{array}$ \\
\hline 26 & Case Studies on TPM & Malaysian SME experience & $\begin{array}{l}\text { Halim Mad Lazim, T. et } \\
\text { al. (2008). [26] }\end{array}$ \\
\hline 27 & Case Studies on TPM & SWOT analysis & $\begin{array}{l}\text { Mishra, R. P. et al. } \\
(2008) .[27]\end{array}$ \\
\hline 28 & Case Studies on TPM & $\begin{array}{l}\text { Enhancement of Overall Equipment } \\
\text { Effectiveness in a Manufacturing } \\
\text { Industry }\end{array}$ & $\begin{array}{l}\text { Nallusamy, S. et al. } \\
\text { (2017). [28] }\end{array}$ \\
\hline 29 & $\begin{array}{l}\text { TPM implementation in a } \\
\text { achine shop }\end{array}$ & A case study & $\begin{array}{l}\text { Singh, R. et al. (2013). } \\
\text { [29] }\end{array}$ \\
\hline 30 & $\begin{array}{l}\text { TPM implementation in a } \\
\text { achine shop }\end{array}$ & Automated foundry lines & Kukla, S. (2009). [30] \\
\hline 31 & $\begin{array}{l}\text { TPM implementation in a } \\
\text { machine shop }\end{array}$ & $\begin{array}{l}\text { Analysis Foundry Defects for Quality } \\
\text { Improvement of Green Sand Casting }\end{array}$ & Vora, M. J. (2020). [31] \\
\hline 32 & $\begin{array}{l}\text { TPM implementation in a } \\
\text { lean tool }\end{array}$ & To reduce lead time-A case study & $\begin{array}{ll}\text { Ramakrishnan, } & \text { V. } \\
(2017) .[32] & \\
\end{array}$ \\
\hline 33 & $\begin{array}{l}\text { TPM in precision tube } \\
\text { mills }\end{array}$ & A Case study & $\begin{array}{l}\text { Ahuja, I. P. S. et al. } \\
\text { (2009). [33] }\end{array}$ \\
\hline 34 & $\begin{array}{l}\text { Study on lean tools } \\
\text { implementation }\end{array}$ & $\begin{array}{l}\text { In Indian small and medium scale } \\
\text { manufacturing industrie }\end{array}$ & $\begin{array}{l}\text { Ramakrishnan, V. et al. } \\
\text { (2018). [34] }\end{array}$ \\
\hline 35 & $\begin{array}{l}\text { TPM implementation } \\
\text { approach in steel } \\
\text { manufacturing industry }\end{array}$ & $\begin{array}{l}\text { A case study of equipment wise } \\
\text { breakdown analysis }\end{array}$ & $\begin{array}{l}\text { Kumar, S., et al. (2017). } \\
\text { [35] }\end{array}$ \\
\hline 36 & $\begin{array}{l}\text { Sand mould casting } \\
\text { companies }\end{array}$ & Benchmarking of cleaner production & $\begin{array}{l}\text { da Silva, H. G., et al. } \\
(2020) .[36]\end{array}$ \\
\hline 37 & $\begin{array}{l}\text { Implementing lean } \\
\text { paradigm in an Indian } \\
\text { foundry facility }\end{array}$ & A Case study & $\begin{array}{l}\text { Tiwari, S. K., et al. } \\
(2020) . \text { [37] }\end{array}$ \\
\hline 38 & TPM in Steel industry & $\begin{array}{l}\text { Productivity improvement through } \\
\text { identifying hazardous condition }\end{array}$ & $\begin{array}{l}\text { Bernard, E. et al. } \\
(2020) .[38]\end{array}$ \\
\hline
\end{tabular}

\section{HYPOTHESIS OF THE STUDY :}

Ho1: Organization implementing TPM does not have any impact towards problems encountered while implementing TPM

Ho2: Age don't have any relation towards behavior of employees change after TPM implementation

\section{RESEARCH METHODOLOGY :}

Type of Research: The study was descriptive in nature.

Data and sources of data

Primary data: The primary data was collected through survey method were scaling point was used for the study were Poor was given 1 and Very good-5

Secondary data: Secondary data was used to collect information about TPM and its implementation using 
International Journal of Management, Technology, and Social

journals and websites.

Population \& Sample Size

130 employees working in foundry industry in Coimbatore was taken as sample size of the study.

Sampling Technique: Simple random sampling was used as type of sample for the study.

Statistical tools used: Descriptive statistics, Kruskal-Wallis test, One-way Anova, Linear regression model Rank correlation and SEM analysis.

8. ANALYSIS AND INTEPRETATION :

Table 2: Demographic and socio graphic variables taken for the study

\begin{tabular}{|c|c|c|c|}
\hline $\begin{array}{c}\text { Demographic and socio } \\
\text { graphic variables taken } \\
\text { for the study }\end{array}$ & Particulars & Frequency & Percent \\
\hline \multirow{4}{*}{ Age } & $20-25$ & 45 & 34.6 \\
\hline & $26-30$ & 54 & 41.6 \\
\hline & $35-40$ & 31 & 23.8 \\
\hline & Total & 130 & 100 \\
\hline \multirow{4}{*}{ Industrial experience } & Less than one year & 30 & 23.1 \\
\hline & 13 years & 11 & 8.4 \\
\hline & 35 years & 89 & 68.5 \\
\hline & Total & 130 & 100 \\
\hline \multirow{4}{*}{$\begin{array}{l}\text { Classification of the } \\
\text { organization }\end{array}$} & Top & 36 & 27.7 \\
\hline & Middl & 34 & 26.1 \\
\hline & Lower & 60 & 46.2 \\
\hline & Total & 130 & 100 \\
\hline \multirow{6}{*}{$\begin{array}{l}\text { Basis of goods } \\
\text { manufactured }\end{array}$} & Make to stock & 43 & 33.1 \\
\hline & Assemble to orde & 24 & 18.5 \\
\hline & Make to orde & 11 & 8.4 \\
\hline & Engineer to orde & 17 & 13.1 \\
\hline & Other & 35 & 26.9 \\
\hline & Total & 130 & 100 \\
\hline \multirow{4}{*}{$\begin{array}{l}\text { Methodology adopted by } \\
\text { the company }\end{array}$} & Intermittent job manufacturing & 89 & 68.5 \\
\hline & $\begin{array}{l}\text { Intermittent batch manufacturing } \\
\text { Intermittent }\end{array}$ & 21 & 16.1 \\
\hline & Project manufacturing & 20 & 15.4 \\
\hline & Total & 130 & 100 \\
\hline \multirow{4}{*}{$\begin{array}{l}\text { Products sold with the } \\
\text { market }\end{array}$} & Local/domesti & 94 & 72.3 \\
\hline & National & 20 & 15.4 \\
\hline & International & 16 & 12.3 \\
\hline & Total & 130 & 100 \\
\hline
\end{tabular}

Out of 130 respondents $34.6 \%$ are from the age group between $20-25,41.5 \%$ are from the age group between $26-30$, and $23.8 \%$ are from the age group between $35-40.23 .1 \%$ are having less than one year of industrial experience, $8.5 \%$ are having experience between $1-3$ years and $68.5 \%$ are having experience between 3-5 years. It shows that most of the respondents are having experience between 3-5 years. $27.7 \%$ are from top 
International Journal of Management, Technology, and Social

level management, 26.2\% are from middle level management, and $46.2 \%$ are from lower level management. $33.1 \%$ said that the company is manufacturing to make stock, $18.5 \%$ said that the company is manufacturing to assemble to order, $8.5 \%$ said as make to order, $13.1 \%$ said as engineer to order and $26.9 \%$ said as other factors. $68.5 \%$ said that the company has adopted intermittent job manufacturing with the department, $16.2 \%$ said as intermittent batch manufacturing intermittent and $15.4 \%$ said as project manufacturing. $72.3 \%$ said that the products are sold with local markets, $15.4 \%$ said as national markets and $12.3 \%$ said as international markets (Table 2).

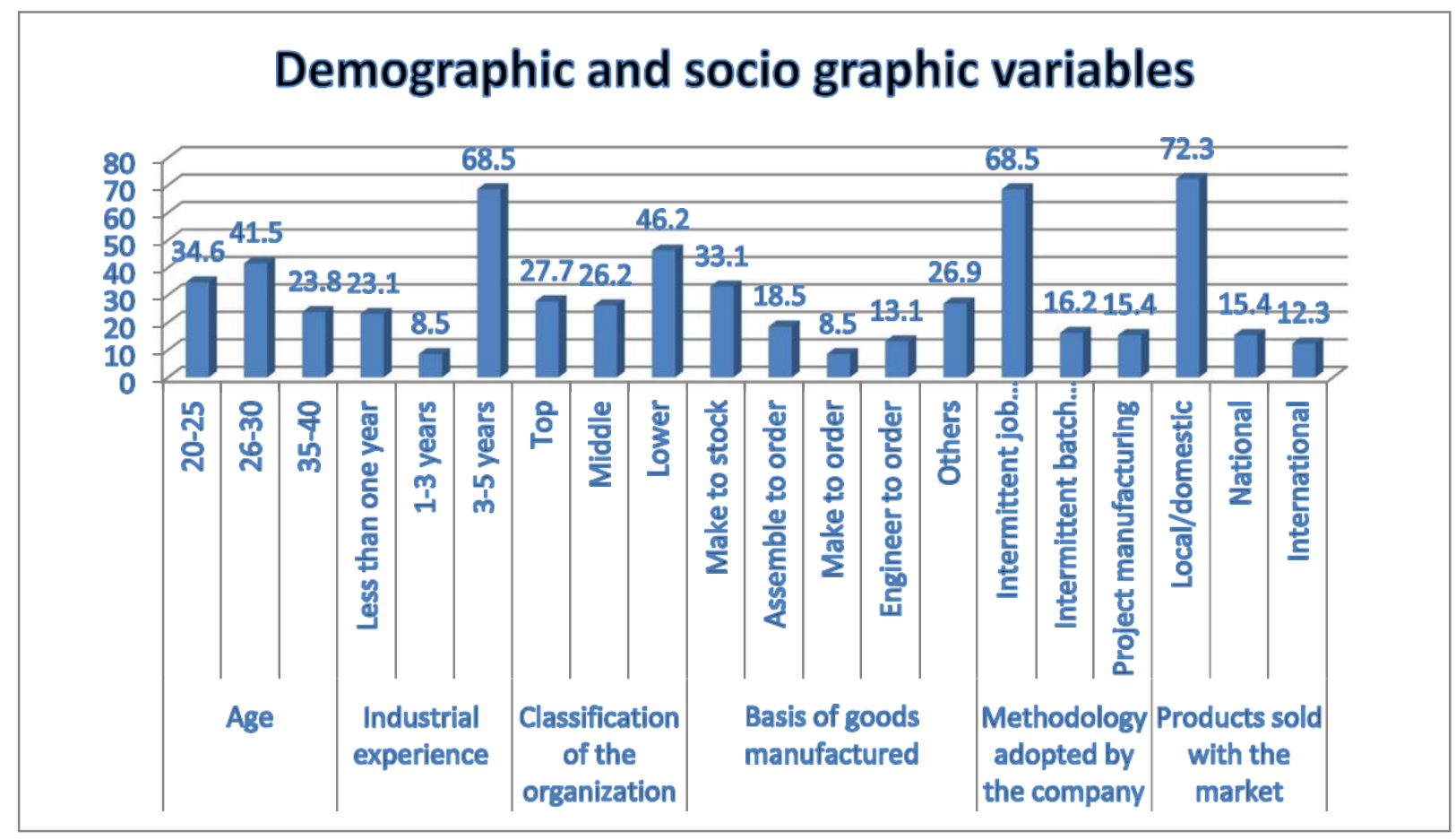

Chart 1 : Demographic and socio graphic variables taken for the study

Table 3: Organization implementing TPM

\begin{tabular}{|l|r|r|}
\hline Particulars & Frequency & \multicolumn{1}{|c|}{ Percent } \\
\hline Ye & 111 & 85.4 \\
\hline No & 19 & 14.6 \\
\hline Total & 130 & 100.0 \\
\hline
\end{tabular}

$85.4 \%$ said that the company have implemented TPM in their department and $14.6 \%$ said that the company have not implemented TPM in their department. 
International Journal of Management, Technology, and Social

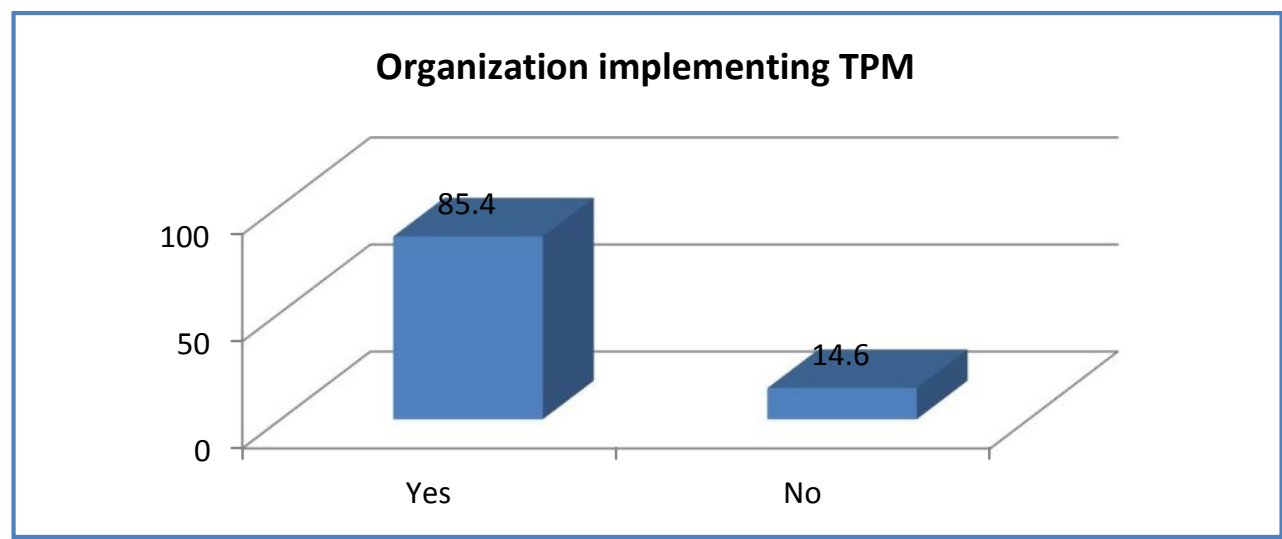

Chart 2: Organization implementing TPM

Table 4: Duration of organization implementing TPM

\begin{tabular}{|l|r|r|}
\hline \multicolumn{1}{|c|}{ Particulars } & \multicolumn{1}{c|}{ Frequency } & \multicolumn{1}{c|}{ Percent } \\
\hline 1 year before & 33 & 29.8 \\
\hline 1 2 years befor & 14 & 12.6 \\
\hline 3 5 years befor & 14 & 12.6 \\
\hline 10 years befor & 50 & 45.0 \\
\hline Total & 111 & 100.0 \\
\hline
\end{tabular}

$29.8 \%$ said that their department have implements TPM before one year, $12.6 \%$ said as 2 years, $12.6 \%$ said as 3-5 years and $45 \%$ said as more than 10 years.

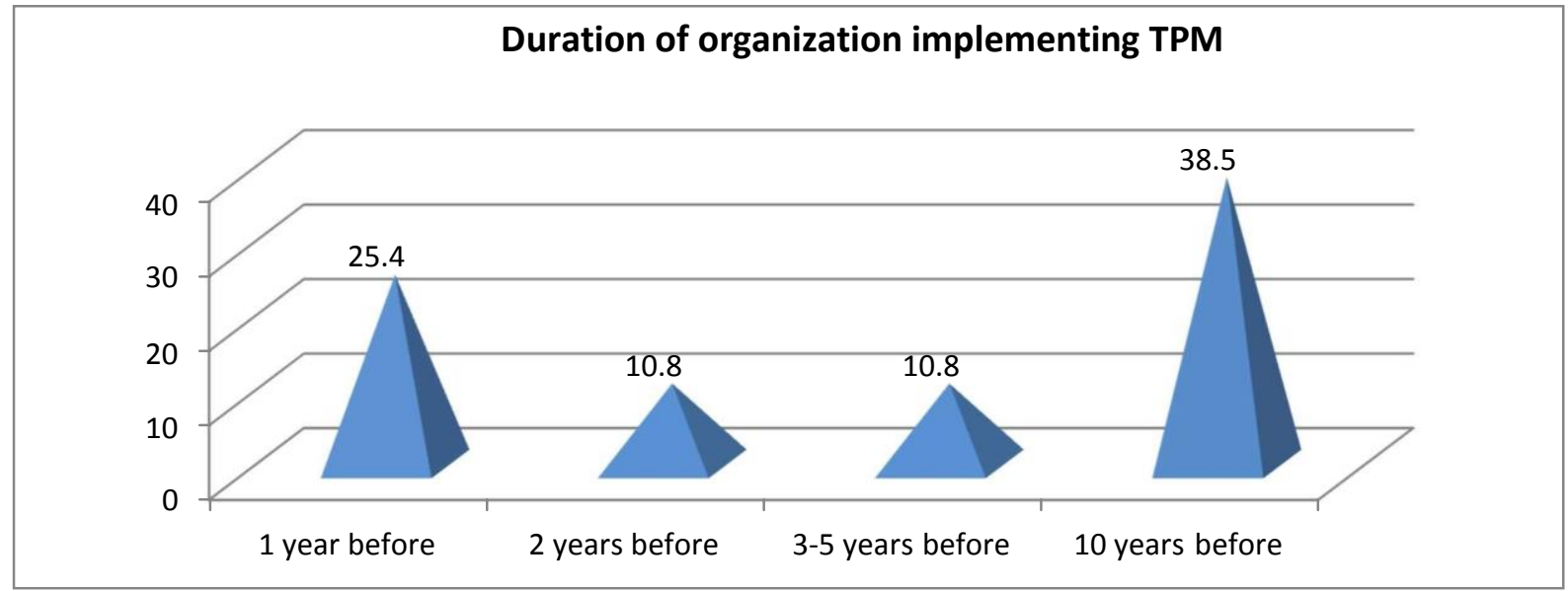

Chart 3: Duration of organization implementing TPM

Table 5: Company having separate TPM office

\begin{tabular}{|l|r|r|}
\hline Particular & Frequency & \multicolumn{1}{|c|}{ Percent } \\
\hline Ye & 106 & 81.5 \\
\hline No & 24 & 18.5 \\
\hline Total & 130 & 100.0 \\
\hline
\end{tabular}

Elamaran N. et al (2020); www.srinivaspublication.com 
International Journal of Management, Technology, and Social

$81.5 \%$ said the company is having separate TPM office and $18.5 \%$ said that the company is not having TPM office.

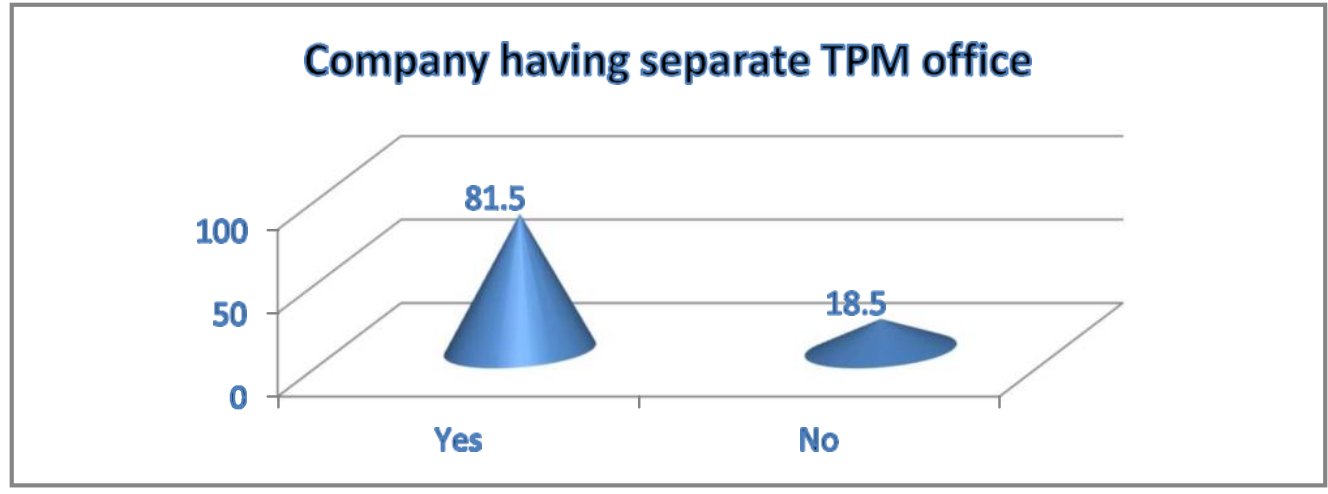

Chart 4: Company having separate TPM office

Table 6: Roles played during TPM implementation as being production executive

\begin{tabular}{|l|r|r|}
\hline \multicolumn{1}{|c|}{ Particular } & \multicolumn{1}{c|}{ Frequency } & \multicolumn{1}{c|}{ Percent } \\
\hline Motivator & 35 & 26.9 \\
\hline Communicator & 23 & 17.7 \\
\hline Leader & 17 & 13.1 \\
\hline Facilitator & 21 & 16.2 \\
\hline Invigilator & 34 & 26.2 \\
\hline Total & 130 & 100.0 \\
\hline
\end{tabular}

$26.9 \%$ said that they are playing motivator role, $17.7 \%$ are playing as communicator, $13.1 \%$ are playing as leader, $16.2 \%$ are playing as facilitator and $26.2 \%$ are playing as investigator.

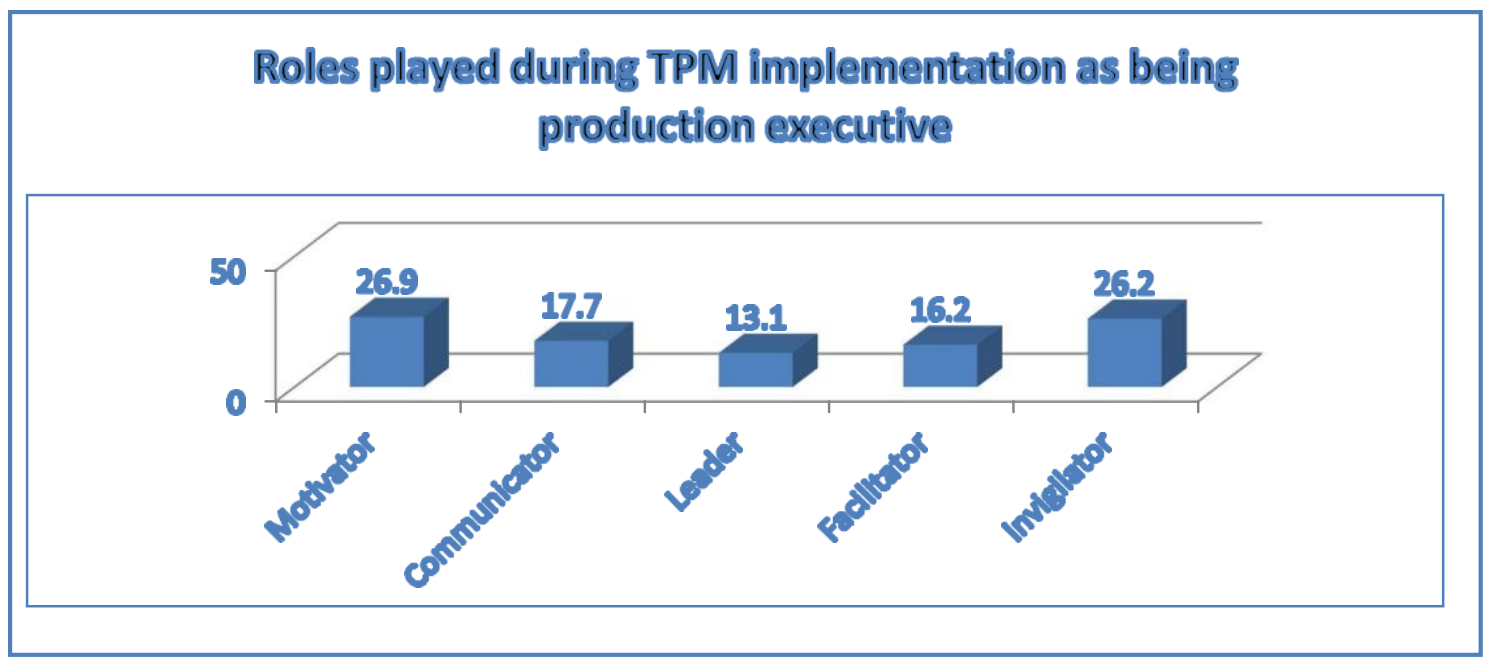

Chart 5: Roles played during TPM implementation as being production executive 
International Journal of Management, Technology, and Social

Table 7: Status of TPM in the organization

\begin{tabular}{|l|r|r|}
\hline Particulars & \multicolumn{1}{|c|}{ Frequency } & \multicolumn{1}{c|}{ Percent } \\
\hline Excellent & 33 & 25.4 \\
\hline Good & 16 & 12.3 \\
\hline Fair & 18 & 13.8 \\
\hline Poor & 23 & 17.7 \\
\hline Failure & 40 & 30.8 \\
\hline Total & 130 & 100.0 \\
\hline
\end{tabular}

$25.4 \%$ said as excellent, $12.3 \%$ said as good, $13.8 \%$ said as fair, $17.7 \%$ said as poor and $30.8 \%$ said as failure.

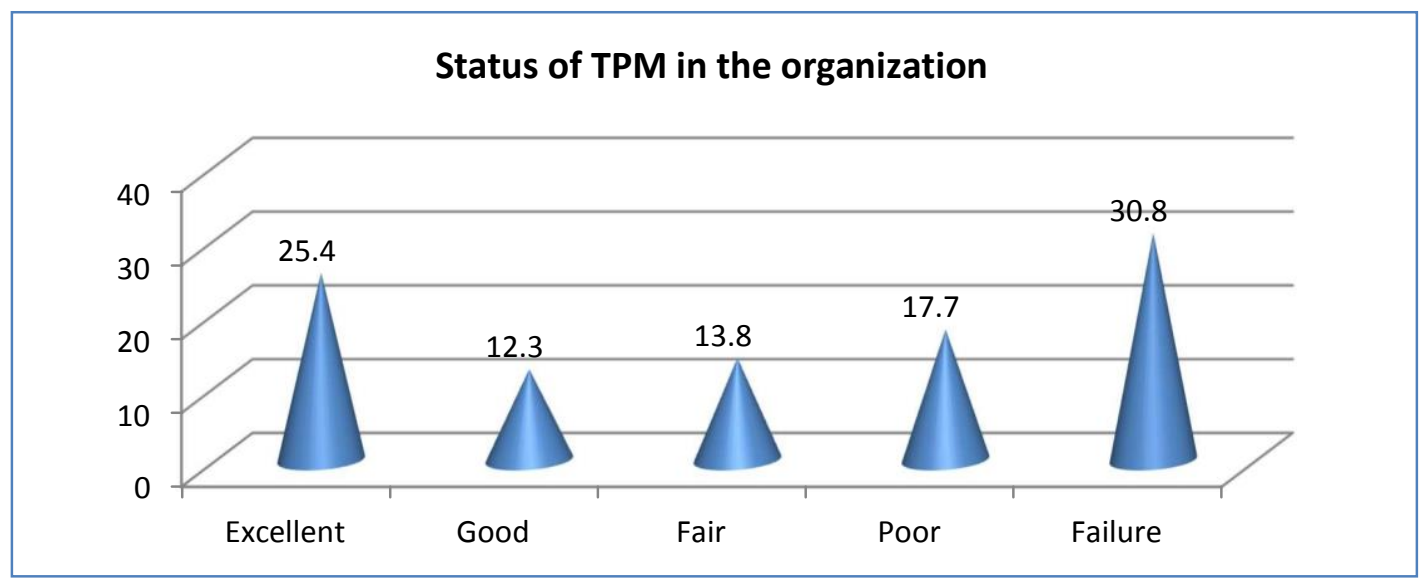

Chart 6: Status of TPM in the organization

Table 8: Time taken by the organization for full implementation of TPM

\begin{tabular}{|l|r|r|}
\hline \multicolumn{1}{|c|}{ Particulars } & Frequency & \multicolumn{1}{c|}{ Percent } \\
\hline Less than 3 months & 37 & 28.5 \\
\hline Between 3 to 6 month & 55 & 42.3 \\
\hline Between 6 to 12 months & 17 & 13.1 \\
\hline Between 1 to 3 year & 21 & 16.1 \\
\hline Total & 130 & 100.0 \\
\hline
\end{tabular}

$28.5 \%$ are taking less than 3 months, $42.3 \%$ are taking between 3 to 6 months, $13.1 \%$ are taking between 6 to 12 months and $16.2 \%$ are taking between 1 to 3 years. 
International Journal of Management, Technology, and Social

Time taken by the organization for full implementation of TPM

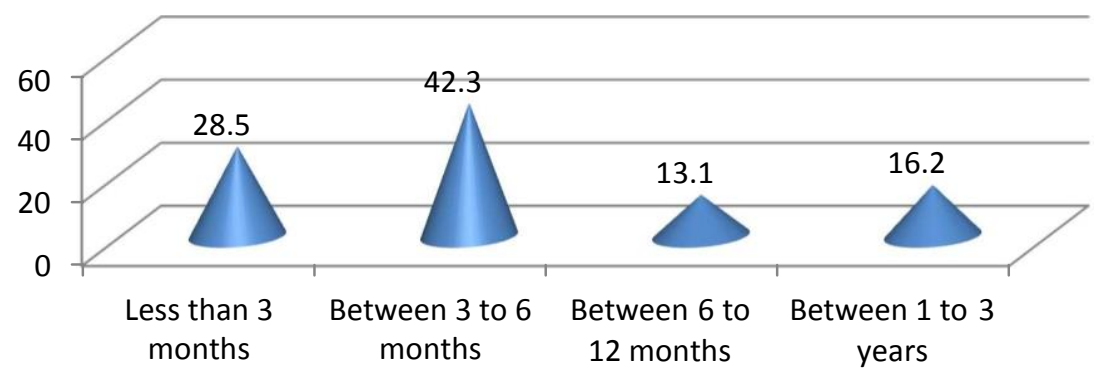

Chart 7: Time taken by the organization for full implementation of TPM

Table 9: Strategies used for successful implementation of TPM

\begin{tabular}{|l|r|r|}
\hline Particulars & Frequency & \multicolumn{1}{|c|}{ Percent } \\
\hline Creating awarenes & 28 & 21.5 \\
\hline Proper Communication & 13 & 10.0 \\
\hline Motivation & 14 & 10.8 \\
\hline Training & 19 & 14.6 \\
\hline Availability of required tools & 34 & 26.2 \\
\hline Delegation of Authority & 10 & 7.7 \\
\hline Assigning ownership & 12 & 9.2 \\
\hline Total & 130 & 100.0 \\
\hline
\end{tabular}

$21.5 \%$ said that the company is creating awareness for successful implementation of TPM, $10 \%$ said as proper communication, $10.8 \%$ said as motivation, $14.6 \%$ said as training, $26.2 \%$ said as availability of required tools, $7.7 \%$ said as delegation of authority and $7.7 \%$ said as assigning ownership.

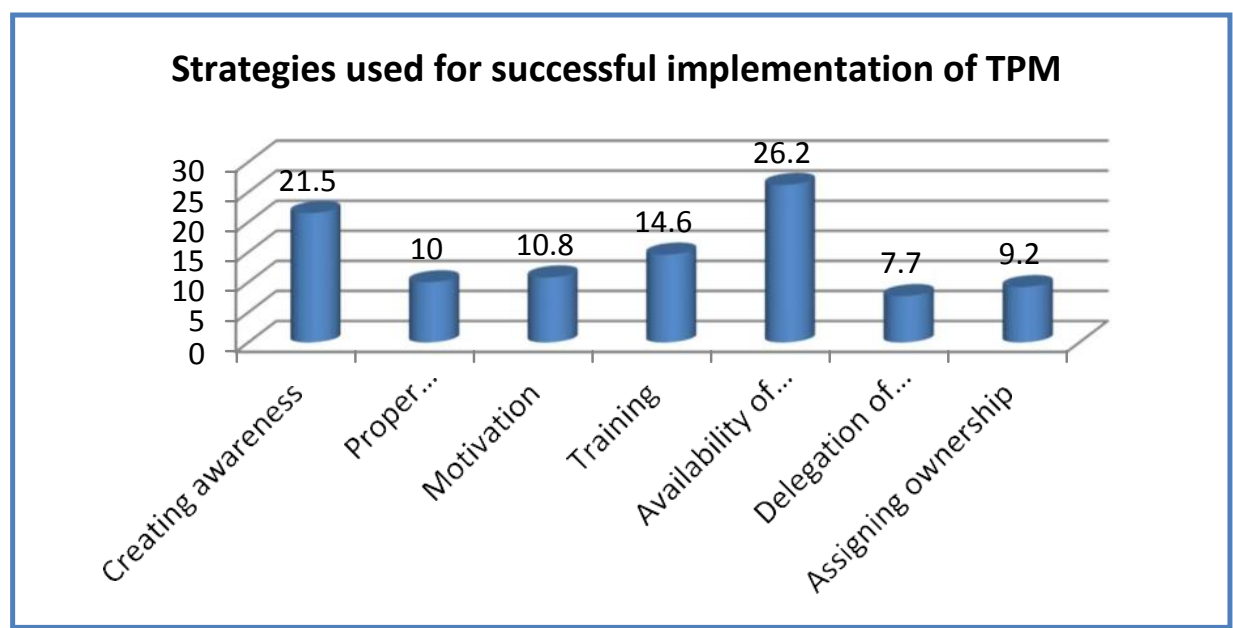

Chart 8: Strategies used for successful implementation of TPM 
International Journal of Management, Technology, and Social Sciences (IJMTS), ISSN: 2581-6012, Vol. 5, No. 2, September 2020.

Table 10: Successfulness towards strategies implemented with TPM

\begin{tabular}{|l|r|r|}
\hline Particulars & Frequency & \multicolumn{1}{|c|}{ Percent } \\
\hline Very Successful & 32 & 24.6 \\
\hline Successful & 20 & 15.4 \\
\hline $\begin{array}{l}\text { Neither Successful Nor } \\
\text { Unsuccessful }\end{array}$ & 22 & 16.9 \\
\hline Unsuccessful & 21 & 16.2 \\
\hline Very Unsuccessful & 35 & 26.9 \\
\hline Total & 130 & 100.0 \\
\hline
\end{tabular}

$24.6 \%$ said as very successful, $15.4 \%$ said as successful, $16.9 \%$ said as neither successful nor unsuccessful, $16.2 \%$ said as unsuccessful and $26.9 \%$ said as very unsuccessful.

H01: Age have a significant difference towards behavior of employees change after TPM implementation.

Table 11: Comparison between age and behavior of employees change after TPM implementation

\begin{tabular}{|c|c|c|c|c|c|c|}
\hline Particulars & Age & $\mathbf{N}$ & Mean & Std. Deviation & $\mathbf{F}$ & Sig \\
\hline \multirow{4}{*}{$\begin{array}{l}\text { Changes towards morale and attitude of the } \\
\text { employee after implementation of TPM }\end{array}$} & $20-25$ & 45 & 3.16 & 1.580 & \multirow{4}{*}{0.133} & \multirow{4}{*}{0.875} \\
\hline & 26-30 & 54 & 3.22 & 1.562 & & \\
\hline & $35-40$ & 31 & 3.03 & 1.816 & & \\
\hline & Total & 130 & 3.15 & 1.621 & & \\
\hline \multirow{4}{*}{$\begin{array}{l}\text { Changes towards creativity of the employee } \\
\text { after implementation of TPM }\end{array}$} & $20-25$ & 45 & 2.87 & 1.660 & \multirow{4}{*}{1.139} & \multirow{4}{*}{0.024} \\
\hline & 26-30 & 54 & 2.91 & 1.605 & & \\
\hline & $35-40$ & 31 & 3.39 & 1.542 & & \\
\hline & Total & 130 & 3.01 & 1.611 & & \\
\hline \multirow{4}{*}{$\begin{array}{l}\text { Changes towards initiative of the employee } \\
\text { after implementation of TPM }\end{array}$} & $20-25$ & 45 & 3.24 & 1.640 & \multirow{4}{*}{0.173} & \multirow{4}{*}{0.842} \\
\hline & $26-30$ & 54 & 3.06 & 1.676 & & \\
\hline & $35-40$ & 31 & 3.19 & 1.621 & & \\
\hline & Total & 130 & 3.15 & 1.640 & & \\
\hline \multirow{4}{*}{$\begin{array}{l}\text { Changes towards belonging } \\
\text { commitment of the employee after } \\
\text { implementation of TPM }\end{array}$} & $20-25$ & 45 & 2.98 & 1.588 & \multirow{4}{*}{0.738} & \multirow{4}{*}{0.480} \\
\hline & $26-30$ & 54 & 2.81 & 1.415 & & \\
\hline & $35-40$ & 31 & 3.23 & 1.521 & & \\
\hline & Total & 130 & 2.97 & 1.499 & & \\
\hline \multirow{4}{*}{$\begin{array}{l}\text { Changes towards problem solving nature of } \\
\text { the employee after implementation of TPM }\end{array}$} & $20-25$ & 45 & 3.09 & 1.769 & \multirow{4}{*}{1.150} & \multirow{4}{*}{0.020} \\
\hline & $26-30$ & 54 & 3.20 & 1.583 & & \\
\hline & $35-40$ & 31 & 3.65 & 1.473 & & \\
\hline & Total & 130 & 3.27 & 1.627 & & \\
\hline \multirow{4}{*}{$\begin{array}{l}\text { Changes towards Co-operation \&amp; Co- } \\
\text { ordination of the employee after } \\
\text { implementation of TPM }\end{array}$} & $20-25$ & 45 & 3.33 & 1.581 & \multirow{4}{*}{2.096} & \multirow{4}{*}{0.127} \\
\hline & $26-30$ & 54 & 2.72 & 1.485 & & \\
\hline & $35-40$ & 31 & 2.94 & 1.340 & & \\
\hline & Total & 130 & 2.98 & 1.499 & & \\
\hline
\end{tabular}

Elamaran N , et al, (2020); www.srinivaspublication.co 
International Journal of Management, Technology, and Social

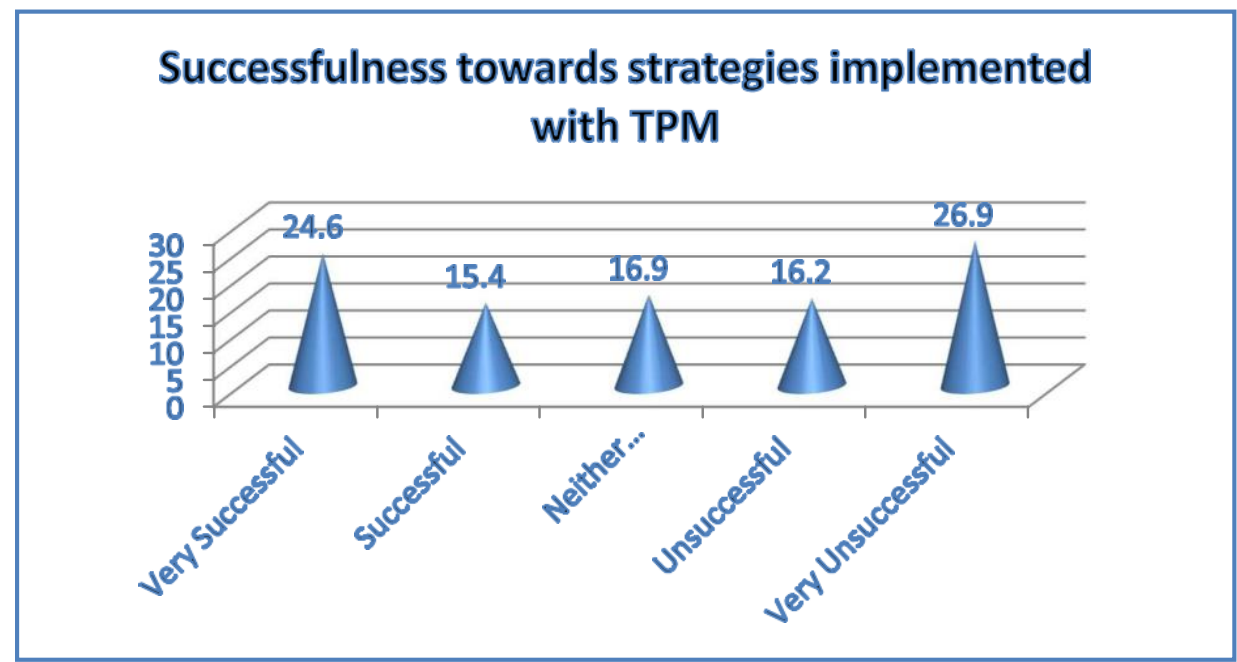

Chart 9: Successfulness towards strategies implemented with TPM

Table 12: Comparison between organization implementing TPM and problems encountered while implementing TPM

\begin{tabular}{|c|c|c|c|c|c|}
\hline Problems & $\begin{array}{c}\text { Organization } \\
\text { implementing } \\
\text { TPM }\end{array}$ & $\mathbf{N}$ & Mean Rank & Chi-Square & Sig \\
\hline \multirow{3}{*}{$\begin{array}{l}\text { Problem with resistance to } \\
\text { change }\end{array}$} & $\mathrm{Ye}$ & 111 & 68.85 & \multirow{3}{*}{.185} & \multirow{3}{*}{.667} \\
\hline & No & 19 & 45.92 & & \\
\hline & Total & 130 & & & \\
\hline \multirow{3}{*}{$\begin{array}{l}\text { Problem with top management } \\
\text { support }\end{array}$} & Ye & 111 & 63.09 & \multirow{3}{*}{.002} & \multirow{3}{*}{.963} \\
\hline & No & 19 & 79.61 & & \\
\hline & Total & 130 & & & \\
\hline \multirow[t]{3}{*}{ Problem with lack of funds } & $\mathrm{Ye}$ & 111 & 67.33 & \multirow{3}{*}{.458} & \multirow{3}{*}{.499} \\
\hline & No & 19 & 54.79 & & \\
\hline & Total & 130 & & & \\
\hline \multirow{3}{*}{$\begin{array}{l}\text { Problem with lack of experience } \\
\text { and awareness }\end{array}$} & $\mathrm{Ye}$ & 111 & 64.98 & \multirow{3}{*}{1.863} & \multirow{3}{*}{.172} \\
\hline & No & 19 & 68.53 & & \\
\hline & Total & 130 & & & \\
\hline \multirow{3}{*}{$\begin{array}{l}\text { Problem with lack of proper } \\
\text { training }\end{array}$} & $\mathrm{Ye}$ & 111 & 65.55 & \multirow{3}{*}{.044} & \multirow{3}{*}{.834} \\
\hline & No & 19 & 65.21 & & \\
\hline & Total & 130 & & & \\
\hline \multirow[t]{3}{*}{ Problem with lack of Leadership } & Yes & 111 & 70.56 & \multirow{3}{*}{.091} & \multirow{3}{*}{.762} \\
\hline & No & 19 & 35.95 & & \\
\hline & Total & 130 & & & \\
\hline
\end{tabular}

There is no relationship between age and changes towards morale $(0.875)$, initiative of the employee after implementation of TPM (0.842), belonging and commitment of the employee after implementation $(0.480)$ 
International Journal of Management, Technology, and Social Sciences (IJMTS), ISSN: 2581-6012, Vol. 5, No. 2, September 2020.

and Co-operation and Co-ordination of the employee after implementation of TPM (0.127). There is a relationship between age and changes towards creativity of the employee after implementation of TPM $(0.024)$ and problem solving nature of the employee after implementation of TPM $(0.020)$.

Ho2: No relationship exists between organization implementing TPM and problems encountered while implementing TPM

No relationship between organization implementing TPM and all the problems encountered while implementing TPM.

Table 13: Industrial experience and problems encountered while implementing TPM

\begin{tabular}{|c|c|c|c|c|c|c|}
\hline \multicolumn{7}{|c|}{ Coefficient } \\
\hline & & \multicolumn{2}{|c|}{$\begin{array}{l}\text { Unstandardized } \\
\text { Coefficients }\end{array}$} & \multirow{2}{*}{$\begin{array}{c}\begin{array}{c}\text { Standardized } \\
\text { Coefficients }\end{array} \\
\text { Beta }\end{array}$} & \multirow[b]{2}{*}{$\mathbf{t}$} & \multirow[b]{2}{*}{ Sig. } \\
\hline \multicolumn{2}{|c|}{ Model } & B & Std. Error & & & \\
\hline \multirow[t]{7}{*}{1} & (Constant) & 2.352 & .491 & & 4.794 & .000 \\
\hline & Problem with resistance to chang & .016 & .120 & .013 & .135 & 893 \\
\hline & Problem with top management support & .094 & .109 & -.079 & -862 & 391 \\
\hline & Problem with lack of funds & .133 & .109 & -.111 & 1.218 & 226 \\
\hline & $\begin{array}{l}\text { Problem with lack of experience and } \\
\text { awarenes }\end{array}$ & .000 & .105 & .000 & .004 & .997 \\
\hline & Problem with lack of proper training & .102 & .113 & .083 & .897 & 371 \\
\hline & Problem with lack of Leadership & .170 & .113 & .140 & 1.504 & 135 \\
\hline \multicolumn{7}{|c|}{ a. Dependent Variable: Industrial experienc } \\
\hline \multicolumn{3}{|c|}{$\mathrm{R}$} & \multicolumn{4}{|c|}{$.696^{\mathrm{a}}$} \\
\hline \multicolumn{3}{|c|}{ R Squar } & \multicolumn{4}{|c|}{538} \\
\hline
\end{tabular}

There is a moderate relationship (53.8\%) between the compared variables as the $\mathrm{R}$ square value $(0.538)$ is between 0.3 to 0.7 . It reveals that the problems related with resistance to change (.016), problems related to lack of proper training (.102) and problems based on lack of leadership (.170) have a positive relation towards Industrial experience who are in to Total Productivity Maintenance. Meanwhile, problems related with top management support based on TPM implementation (-.094) and lack funds towards implementing TPM (-

.094) doesn't have any impact on the employees industrial experience.

\section{RANK CORRELATION}

Table 14: Reason for organisation having a separate TPM office by the management

\begin{tabular}{|c|c|c|c|c|}
\hline S.NO & Particulars & $\mathbf{X}$ & $\mathbf{Y}$ & $\mathrm{R}$ \\
\hline 1 & Awareness on TPM & 18 & 36 & \multirow{6}{*}{0.94} \\
\hline 2 & For Involvement and productivity of people in support functions & 15 & 34 & \\
\hline 3 & To reduce administrative costs & 8 & 31 & \\
\hline 4 & To reduce inventory carrying cost & 11 & 28 & \\
\hline 5 & To reduce number of file & 13 & 36 & \\
\hline 6 & To reduce manpower & 12 & 34 & \\
\hline
\end{tabular}


International Journal of Management, Technology, and Social

The correlation is at 0.94 which shows a high relationship between the ranks given. Based on the ranks the priority was given to awareness provided towards all supporting teams as the factor was given first rank.

Table 15: Reason for organisation not having a separate TPM office by the management

\begin{tabular}{|c|c|c|c|c|}
\hline S. NO & Particulars & $\mathbf{X}$ & $\mathbf{Y}$ & $\mathrm{R}$ \\
\hline 1 & Lack of awareness \& importance of TPM & 15 & 15 & \multirow{5}{*}{0.67} \\
\hline 2 & Lack of fund & 16 & 10 & \\
\hline 3 & Lack of facilities available in the company & 85 & 10 & \\
\hline 4 & Lack of manpower & 25 & 45 & \\
\hline 5 & Lack of skill employee & 62 & 64 & \\
\hline
\end{tabular}

The correlation is at 0.67 which shows a moderate relationship between the ranks given. Based on the ranks the priority was given to lack of facilities available in the company as the factor was given first rank.

Table 16: Reason for the organization to choose TPM method instead of other maintenance methods

\begin{tabular}{|c|c|c|c|c|}
\hline S. NO & Particulars & $\mathbf{X}$ & $\mathbf{Y}$ & $\mathbf{R}$ \\
\hline 1 & Easy to implement & 81 & 21 & \multirow{6}{*}{0.77} \\
\hline 2 & Employees' involvement & 33 & 90 & \\
\hline 3 & Elimination of production losse & 25 & 26 & \\
\hline 4 & Maximization of equipment utilization & 6 & 25 & \\
\hline 5 & Avoid wastag & 22 & 10 & \\
\hline 6 & $\begin{array}{l}\text { Increase employees' morale and job } \\
\text { satisfaction }\end{array}$ & 4 & 27 & \\
\hline
\end{tabular}

The correlation is at 0.77 which shows a high relationship between the ranks given. Based on the ranks the priority was given to easy implementation as the factor was given first rank.

\section{SEM analysis}

Impact of problems faced by employees in implementation of TPM towards behavior of employees change after TPM implementation

Table 17: Model fit

\begin{tabular}{|l|c|c|r|r|c|c|}
\hline Model & CMIN & GFI & AGFI & CFI & RMSEA & P value \\
\hline Default model & 41.029 & .835 & .820 & 770 & .076 & 000 \\
\hline
\end{tabular}

It reveals that the GFI value (.835) and AGFI value (.820) are less than .89 and also the RMSEA value (.076) is less than .08 which shows that model can be proceeded for further analysis.

The Chart 10 describes that the employees who face problems related to resistance of change while implementing TPM agree towards creativity and Initiative after implementing TPM with their company. The employees who face problems with top management while implementing TPM agree towards morale and attitude \& creativity after implementing TPM. The organisations who face of problems related to lack of funds agree towards attitude \& morale, creativity and belonging and commitment after implementing TPM with the company. The employees who face problems related to lack of experience and awareness while implementing TPM agree towards change in behaviour based on Lack of experience and awareness, 
Creativity of implementing TPM, Belonging and commitment after implementation and problem solving nature of TPM.

\section{FINDINGS :}

\section{Demographic and socio graphic variables taken for the study}

Most of the respondents are from the age group between 26-30. Maximum of the respondents are having experience between 3- 5 years. Most of the respondents are from lower level management. Maximum of the respondents said as make to stock for basis of goods manufactured by the companies. Most of the respondents said that the company has adopted intermittent job manufacturing with the department. Maximum of the respondents said that the company products are sold with local markets.

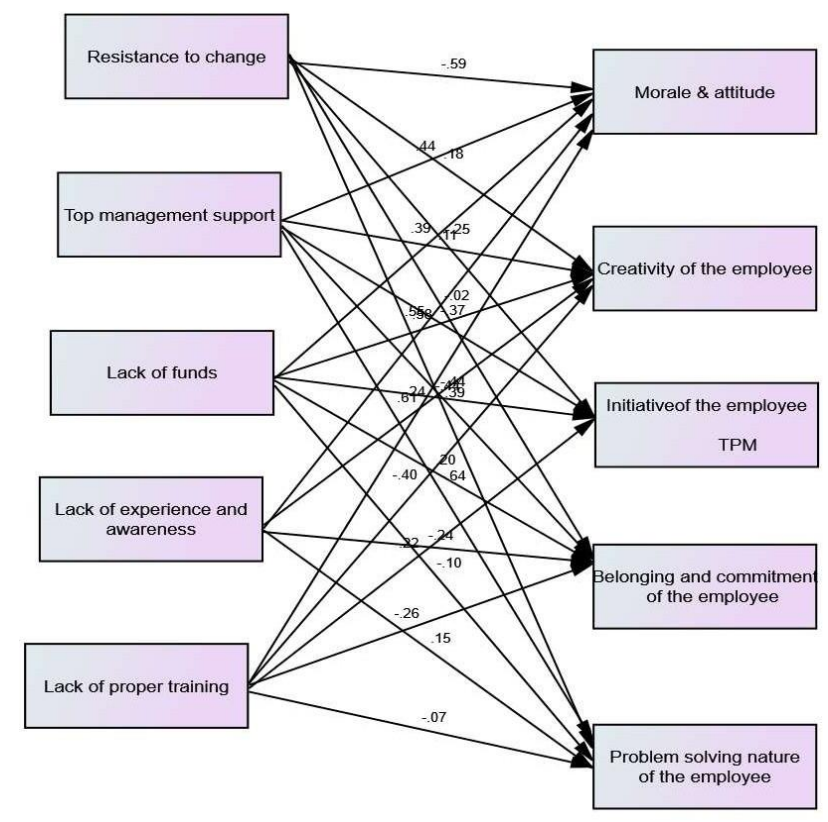

Chart 10: Results towards the model framed

\section{Perception of employees towards TPM with their company.}

Most of the respondents strongly agree towards believing in TPM technology and said that the company have implemented TPM in their department before 10 years. Most of the respondents said that the company is having separate TPM office were the same has been researched by Rodrigues, M et.al., (2006) [39] who analysed about TPM office-efficiency-involvement of the administration in TPM program and maximum are playing as motivator during TPM implementation as being production executive and the same has been analysed by Cooke, F. L. (2000) [40] and found that no unmotivated workers were there at the time of TPM implementation. But with the present study, most of them said as failure towards status of TPM in the organization and maximum of the respondents strongly disagree towards organization having a clear TPM implementation (master) plan as the same has been researched by Kumar, J et.al., [41] and he found out that it is not easy to implement TPM in an organisation. It also reveals that most are taking time between 3 to 6 months for full implementation of TPM as the same has been found out by Jonathan David Morales Méndez et.al., (2017) [42] as he said that it takes 6 months to implement TPM and maximum said that availability of required tools for successful implementation of TPM. 
Maximum of the respondents said as very unsuccessful for strategies implemented with TPM with the organisation as the same has been analysed by Hansson, J., et.al. (2003) [43] and maximum are taking assistance from private consultancy for implementation of TPM. Most of them said as very effective for efficacy of external agencies assistance and maximum of the respondents strongly disagree towards organization providing training before TPM implementation. Most of the respondents strongly disagree towards satisfaction with the training provided by the organization.

Comparison between age and behavior of employees change after TPM implementation : The respondents from the age group between 35-40 have higher impact towards creativity of the employee after implementation of TPM. Meanwhile, the respondents from the age group between 20-25 have higher impact towards changes towards problem solving nature of the employee after implementation of TPM and the same has been discussed by F.T.S. Chan et.al., (2005) [44] and found that tangible and intangible benefits given to employees may reduce the problems related to age of the employees which has an effect to TPM implementation.

Comparison between organization implementing TPM and problems encountered while implementing TPM :

No relationship between organization implementing TPM and all the problems encountered while implementing TPM.

\section{Comparison between industrial experience and problems encountered while implementing} TPM :

The factors Problem with resistance to change, Problem with lack of funds, Problem with lack of experience and awareness, Problem with lack of proper training, Problem with lack of Leadership are directly proportional towards industrial experience.

\section{Reason for organisation having TPM}

- Awareness provided towards all supporting teams was the major reason for organisation having a separate TPM office by the management.

- Lack of facilities available in the company was the major reason for organization for not having a separate TPM office by the management.

- $\quad$ Easy implementation was the reason to choose TPM method instead of other maintenance methods.

10. SUGGESTIONS :

- Top administration requires in order to produce a good atmosphere which will help the particular intro associated with TPM. With no assistance associated with administration, skepticism plus level of resistance will certainly destroy the particular effort.

- The organization may release an official schooling system. This particular system will certainly notify in addition to teach everybody within the business regarding TPM actions, advantages, and even the particular significance of factor through everybody.

\section{CONCLUSION :}

The conclusion is that the TPM is effectively implemented with the organisation and further slight changes has to be made which leads to cost effectiveness towards the company.

\section{REFERENCES :}

[1] Venkatesh, J. (2007). An introduction to total productive maintenance (TPM). The plant maintenance resource center, 3-20.

[2] Andersson, R., Manfredsson, P., \& Lantz, B. (2015). Total productive maintenance in support processes: an enabler for operation excellence. Total Quality Management \& Business Excellence, 26(9-10), 10421055 . 
[3] Brah, S. A., \& Chong, W. K. (2004). Relationship between total productive maintenance and performance. International Journal of Production Research, 42(12), 2383-2401.

[4] Okhovat, M. A., Ariffin, M. K. A. M., Nehzati, T., \& Hosseini, S. A. (2012). Development of world class manufacturing framework by using six-sigma, total productive maintenance and lean. Scientific Research and Essays, 7(50), 4230-4241.

[5] Ahuja, I. P. S. and Khamba, J. S. (2008), Total productive maintenance: literature review and directions. International Journal of Quality \& Reliability Management, 25(7), 709-756.

[6] Gupta, A., \& Khanna, I. K. (2019). An Analysis of Barriers and Enablers for Effective Implementation of Total Productive Maintenance (TPM) in Small and Medium Enterprises (SMEs) in India: Literature Review. International Journal of Modern Engineering \& Management Research, 7(4), 41-61.

[7] Waghmare, S. N., Raut, D. N., Mahajan, S. K., \& Bhamare, S. S. (2014). Failure mode effect analysis and total productive maintenance: A review. International Journal of Innovative Research in Advanced Engineering, 1(6), 183-203.

[8] Sivaram, N. M., Devadasan, S. R., Sreenivasa, C. G., Karthi, S., \& Murugesh, R. (2012). A literature review on the integration of total productive maintenance elements with ISO 9001 standard. International Journal of Productivity and Quality Management, 9(3), 281-308.

[9] One Yoon Seng, Muhamad Jantan, T. Ramayah (2010). Investigation of human aspect in total productive maintenance (TPM): literature review. International Journal of Engineering Research and Development, 5(10), 27-36.

[10] Kulkarni, A., \& Dabade, B. M. (2013). Investigation of human aspect in total productive maintenance (TPM): literature review. International Journal of Engineering Research and Development, 5(10), 2736.

[11] Jain, A., Bhatti, R., \& Singh, H. (2014). Total productive maintenance (TPM) implementation practice. International Journal of Lean Six Sigma. 5(3), 293-323.

[12] Ahuja, I. P. S., \& Khamba, J. S. (2008). Total productive maintenance implementation in a manufacturing organisation. International Journal of Productivity and Quality Management, 3(3), 360381.

[13] Nallusamy, S., Kumar, V., Yadav, V., PRASAD, U. K., \& Suman, S. K. (2018). Implementation of total productive maintenance to enhance the overall equipment effectiveness in medium scale industries. International Journal of Mechanical and Production Engineering Research and Development, 8 (1), 1027, 1038.

[14] Shahanaghi, K., \& Yazdian, S. A. (2009). Analyzing the effects of implementation of Total Productive Maintenance (TPM) in the manufacturing companies: a system dynamics approach. World Journal of Modelling and Simulation, 5(2), 120-129.

[15] Kedaria, V. D., \& Deshpande, V. A. (2014). Implementation of total productive maintenance methodology: a review. International Journal of Emerging Technology and Advanced Engineering, 3(4), 644-648.

[16] Kocher, G., Kumar, R., Singh, A., \& Dhillon, S. S. (2012). An approach for Total Productive Maintenance and factors affecting its implementation in manufacturing environment. International Journal on Emerging Technologies, 3(1), 41-47.

[17] Friedli, T., Goetzfried, M., \& Basu, P. (2010). Analysis of the implementation of total productive maintenance, total quality management, and just-in-time in pharmaceutical manufacturing. Journal of Pharmaceutical Innovation, 5(4), 181-192. 
[18] Attri, R., Grover, S., Dev, N., \& Kumar, D. (2013). An ISM approach for modelling the enablers in the implementation of total productive maintenance (TPM). International Journal of System Assurance Engineering and Management, 4(4), 313-326.

[19] Attri, R., Grover, S., \& Dev, N. (2014). A graph theoretic approach to evaluate the intensity of barriers in the implementation of total productive maintenance (TPM). International Journal of Production Research, 52(10), 3032-3051.

[20] Punna Rao, G. V., Nallusamy, S., Chakraborty, P. S., \& Muralikrishna, S. (2020). Study on Productivity Improvement in Medium Scale Manufacturing Industry by Execution of Lean Tools. In International Journal of Engineering Research in Africa (Vol. 48, pp. 193-207). Trans Tech Publications Ltd.

[21] Kathleen E. McKonea,, Roger G. Schroederb, Kristy O. Cuab (1999). Implementation of total productive maintenance and overall equipment effectiveness evaluation. International Journal of Mechanical \& Mechatronics Engineering, 13(1), 69-75.

[22] Mwanza, B. G., \& Mbohwa, C. (2015). Design of a total productive maintenance model for effective implementation: Case study of a chemical manufacturing company. Procedia Manufacturing, 4, 461470.

[23] Chan, F. T. S., Lau, H. C. W., Ip, R. W. L., Chan, H. K., \& Kong, S. (2005). Implementation of total productive maintenance: A case study. International journal of production economics, 95(1), 71-94.

[24] Masud, A. K. M. Abdullah-Al-Khaled,Seratun Jannat (2007). Total productive maintenance in RMG sector a case: burlingtons limited, Bangladesh. Journal of mechanical engineering, 37, 62-65.

[25] Halim Mad Lazim (2016). Total productive maintenance and performance: A Malaysian SME experience. International Review of Business Research Papers, 4(4), 237-250.

[26] Halim Mad Lazim, T. Ramayah, Norzieiriani Ahmad (2008). Total productive maintenance and performance: A Malaysian SME experience. International Review of Business Research Papers, 4(4), $237-250$

[27] Mishra, R. P., Anand, G., \& Kodali, R. (2008). A SWOT analysis of total productive maintenance frameworks. International Journal of Management Practice, 3(1), 51-81.

[28] Nallusamy, S., \& Majumdar, G. (2017). Enhancement of Overall Equipment Effectiveness using Total Productive Maintenance in a Manufacturing Industry. International Journal of Performability Engineering, 13(2). 173-188.

[29] Singh, R., Gohil, A. M., Shah, D. B., \& Desai, S. (2013). Total productive maintenance (TPM) implementation in a machine shop: A case study. Procedia Engineering, 51, 592-599.

[30] Kukla, S. (2009). Total productive maintenance on example of automated foundry lines. Archives of Foundry Engineering, 9(3), 71-74.

[31] Vora, M. J., \& Patel, D. M. (2020). Review on Analysis of Foundry Defects for Quality Improvement of Green Sand Casting. Studies in Indian Place Names, 40(9), 126-131.

[32] Ramakrishnan, V., \& Nallusamy, S. (2017). Implementation of total productive maintenance lean tool to reduce lead time-A case study. Int. J. Mech. Eng. Technol, 8, 295-306.

[33] Ahuja, I. P. S., \& Kumar, P. (2009). A case study of total productive maintenance implementation at precision tube mills. Journal of Quality in Maintenance Engineering. 15(3), 241-258.

[34] Ramakrishnan, V., Nallusamy, S., \& Rajaram Narayanan, M. (2018). Study on lean tools implementation in various Indian small and medium scale manufacturing industries. International Journal of Mechanical and Production Engineering Research and Development, 8 (1), 969, 976. 
[35] Kumar, S., Raj, B., \& Shubham, S. (2017). Study of total productive maintenance \& it's implementation approach in steel manufacturing industry: A case study of equipment wise breakdown analysis. International Research Journal of Engineering and Technology (IRJET), 4(8), 608-613.

[36] da Silva, H. G., Ferreira, J. C. E., Kumar, V., \& Garza-Reyes, J. A. (2020). Benchmarking of cleaner production in sand mould casting companies. Management of Environmental Quality: An International Journal, 31(5), 1407-1435.

[37] Tiwari, S. K., Singh, R. K., \& Srivastava, S. C. (2020). Implementing lean paradigm in an Indian foundry facility: a case study. International Journal of Services and Operations Management, 36(1), 20-41.

[38] Bernard, E., \& Patange, G. S. (2020, June). Productivity improvement through identifying hazardous conditions in steel foundry. In IOP Conference Series: Materials Science and Engineering (Vol. 872, No. 1, p. 012091). IOP Publishing.

[39] Rodrigues, M., \& Hatakeyama, K. (2006). Analysis of the fall of TPM in companies. Journal of Materials Processing Technology, 179(1-3), 276-279.

[40] Cooke, F. L. (2000). Implementing TPM in plant maintenance: some organisational barriers. International Journal of Quality \& Reliability Management, 17(9), 1003-1016.

[41] Kumar, J., Soni, V. K., \& Agnihotri, G. (2014). Impact of TPM implementation on Indian manufacturing industry. International Journal of Productivity and Performance Management, 63(1), 44-56.

[42] Méndez, J. D. M., \& Rodriguez, R. S. (2017). Total productive maintenance (TPM) as a tool for improving productivity: a case study of application in the bottleneck of an auto-parts machining line. The International Journal of Advanced Manufacturing Technology, 92(1-4), 1013-1026.

[43] Hansson, J., Backlund, F., \& Lycke, L. (2003). Managing commitment: increasing the odds for successful implementation of TQM, TPM or RCM. International Journal of Quality \& Reliability Management.

[44] Chan, F. T. S., Lau, H. C. W., Ip, R. W. L., Chan, H. K., \& Kong, S. (2005). Implementation of total productive maintenance: A case study. International journal of production economics, 95(1), 71-94.

$* * * * * * * *$ 